\title{
BONCOLÁS NYOMAI EGY XVIII. SZÁZADI GYERMEK MUMIFIKÁLÓDOTT TESTÉN
}

\author{
Szikossy Ildikó ${ }^{1,2}$, Karlinger Kinga ${ }^{3}$, Pálfi György és Pap Ildikóo ${ }^{1,2,4}$
}

\begin{abstract}
${ }^{1}$ Embertani tár, Magyar Természettudományi Múzeum, Budapest; ${ }^{2}$ Embertani Tanszék, Szegedi Tudományegyetem, Szeged; ${ }^{3}$ Radiológiai Klinika, Semmelweis Egyetem, Budapest; ${ }^{4}$ Embertani Tanszék, Eötvös Loránd Tudományegyetem; Budapest
\end{abstract}

Szikossy I., Karlinger K., Pálfi Gy., Pap I.: Signs of autopsy on the body of a 10-year-old girl lived in the 18th century. In 1994-1995, in the Church of the Whites, the corpses of 265 individuals dressed in funeral clothes, mummified to varying degrees, were unearthed from coffins excavated by the ethnographic museologists of the Ignác Tragor Museum, Vác (Hungary). The individuals were preserved by spontaneous mummification due to the crypt's unique microclimate and burial pattern.

Signs of an autopsy were found on the body of a 10-year old girl, Maria Theresa of Swartz, who died on the 26th January 1784.

Two incisions were seen on her body: the longitudinal incision extends from the manubrium sterni to the symphysis, the second one is perpendicular to it, and connects the two hip paddles. The wound edges were later sutured, and the suture was partially retained. Since there was no sign of any other opening in the body, the autopsy was apparently aimed at finding out the cause of death and was limited to the area of the suspected disease. Rapid miliary tuberculosis and extrapulmonary bone tuberculosis must have contributed to the child's death; this was demonstrated by radiological examinations and confirmed by paleomicrobiological examination (residues of Mycobacterium tuberculosis detected in pulmonary and extrapulmonary samples as well). Another hypothesis is that appendicitis might have caused the death of a child with advanced tuberculosis. In the case of appendicitis, the intestinal function may stop. Suspected abdominal complaints may also have been caused by extrapulmonary gastrointestinal tuberculosis.

Keywords: Vác Mummy Collection; Autopsy; 18th century; Crypt mummies; Child mummy.

\section{Bevezetés}

A váci Fehérek templomának kriptájában 1994-1995-ben folytatott feltárás során 265 halotti ruhába öltöztetett egyén mumifikálódott holtteste, valamint egy osszárium került elő (Tragor Ignác Múzeum 1995, Zomborka 1996, Pap és mtsai 1997, Szikossy és mtsai 1997).

A koporsókra festett évszámok és az anyakönyvi bejegyzések tanúsága szerint a kriptát Vác lakosai, polgári és egyházi személyek folyamatosan temetkezési helyül használták 1731-1808 között.

A kriptába temetettek a kripta mikroklímájának és a temetkezés módjának köszönhetően természetes úton mumifikálódtak (Susa 1995, Susa és Józsa 1995, Pap és mtsai 1999).

Az antropológiai leleteket a Magyar Természettudományi Múzeum Embertani tára örzi. 
A váci múmiák multidiszciplináris kutatása során képet kapunk az egykor Vácott élt emberek életéről, betegségeiről és mindennapjairól.

A múmiák antropológiai vizsgálata során egy fiatal kislány testén boncolásra utaló vágásnyomokat fedeztünk fel (1. ábra). A feltárási jegyzőkönyv és a fotódokumentáció szerint a koporsóban a 10 éves korában elhunyt Swartz Maria Terézia holtteste feküdt.

\section{Anyag és módszer}

A vizsgálat anyaga

Vizsgálatainkat a néhai Swartz Mária Terézia mumifikálódott maradványain végeztük.

Szám: 76.

Leltári szám: 2009.19.76.

Név: Swartz Mária Terézia

Nem: nő

Kor: 10 éves

Halál dátuma: 1784. január 26.

Feltárás dátuma: 1995. január 19.

A koporsón szereplő felirat: Maria Deresia schwartzlin/ihres alters in 10 jahr 1784.

A koporsón szereplö felirat fordítása: Schwartzel Mária Terézia, (meghalt) 1784-ben, 10 éves korában.

A halotti anyakönyvi bejegyzés: Anna Maria Josephi Swartzl, an 5.

A halotti anyakönyvi bejegyzés fordítása: Swartzl József Anna Mária nevủ lánya 5 éves korában meghalt.

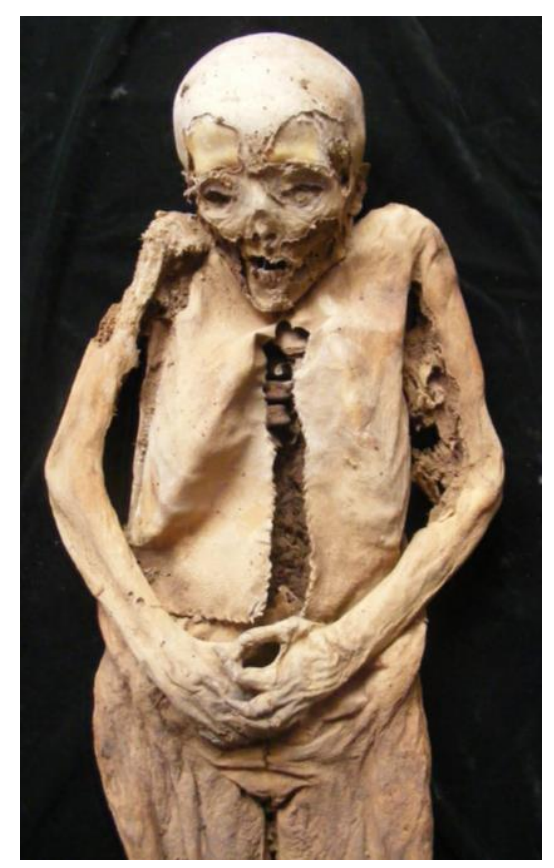

1. ábra: Swartz Mária Terézia mumifikálódott teste a boncolás nyomával (fotó: Szikossy Ildikó). Fig. 1: Mária Terézia Swartz's mummified body with traces of autopsy (photo: Ildikó Szikossy). 


\section{Alkalmazott módszerek}

A test makroszkópos megfigyelését követő radiológiai vizsgálatokat az Országos Gyógyintézeti Központban, majd a Semmelweis Egyetem Radiológiai Klinikáján végeztük. A CT-felvételek Philips Brillance 16 spirál CT-készülékkel, 1 mm-es szelet vastagságot alkalmazva készültek. A CT-szeletek megtekintéséhez a Radiant DICOM Wiever 5.0.1. programot használtuk. A felvételek értékelésekor többször ablakot váltottunk, attól függően, hogy mely részeket akartuk megtekinteni. Magas ablakközép (WL - window level) és keskeny ablakszélesség (WW - window width) beállítása esetén a meszes részek ábrázolódnak jobban. Ez a beállítás a csontok elemzésére használandó. A lágyrészek ugyanakkor fordítva vizsgálhatók. Az ablakértékek változtatásával ki tudjuk választani, hogy az adott CT-szeletnél mit szeretnénk megtekinteni.

Korábbi kutatásunk során a University College London munkatársaival együttműködésben paleomikrobiológiai vizsgálatokat végeztünk, amelynek során Swartz Mária Terézia múmiáját is elemeztük. Célunk a csontokban és a mumifikálódott szövetekben megőrződött Mycobacterium tuberculosis komplex DNS-ének kimutatása volt.

\section{Vizsgálati eredmények és megvitatásuk}

\section{Makroszkópos vizsgálatok}

Első lépésben, mivel ellentmondás van a koporsón és az anyakönyven lévő életkor között a gyermek életkorát becsültük. A makroszkópos vizsgálat, főleg a maradó fogak előbúvása a 10 éves életkort erősítette meg.

A mumifikálódott kislány Berkow-értéke (a vizsgálható testfelszín százalékos mértéke) 55,4\% (Cseplák és mtsai 2016). A holttesten a makroszkópos vizsgálat során két hosszú bőrvágás figyelhető meg. A mellkason, a manubrium sterni magasságában kezdődő longitudinális vágás egészen a symphysisig tart. Az abdominalis részen a hosszanti metszésre meröleges, haránt irányú, széles, a két csípőlapátot összekötő második vágás látható (1. ábra). A vágások egyértelmüen halál utáni beavatkozásra utalnak, a korabeli boncolás nyomai.

Megállapítható, hogy a boncolás végén a sebszéleket varrással egyesítették. A varrást sürü, alapos öltésekkel végezték, néhol még megörződött a megmaradt növényi eredetü varrófonal. A metszésvonalak mára eltávolodtak egymástól, így kissé beláthatunk a testüregbe. A fejen erőteljes rovarkár figyelhető meg, szinte az egész arcot lerágták a lárvák, amelyről a nagyszámú hátrahagyott lárvabőr is tanúskodik. A fejen semmilyen boncolási nyom nem látható, amely a koponya megnyitására utalna.

A test tartása alapján megállapíthatjuk, hogy a kislányt mindenképp már a hullamerevség feloldódása után helyezték a koporsóba.

\section{Radiológiai vizsgálatok}

A hagyományos röntgenvizsgálatokat az Országos Gyógyintézeti Központban végeztük. A radiológiai felvételen jól látható, hogy a halál bekövetkezte után megindult bomlás a test háti felszínét érintette a legnagyobb mértékben. A hasüregben alig észlelhetők a belső szervek nyomai. Az ágyéki és alsó háti csigolyák nem anatómiai helyzetben vannak. Ezek valószínüleg a feltárás során mozdultak el és estek ki a testből.

Jól kivehető, hogy a medence csontjai még nem csontosodtak teljesen össze. A combcsonton jól látszódik az epiphysis fuga. A trochanter major sem csontosodott még teljes egészében a femurhoz. 
A tibia distalis végén több Harris-vonal is kivehető. A Harris-vonalak létrejötte, illetve megléte súlyos, gyermekkorban lezajlott, hosszantartó lázzal vagy hosszú ideig tartó éhezéses állapottal járó betegségre utalhat. Swartz Mária Terézia esetében a tartós éhezés miatti növekedésmegtorpanás kevésbé valószínü, mert a család viszonylag jó módban élt. Erre utal az is, hogy a kereskedő apa megengedhette magának, hogy gyermekét a Dominikánusok templomának kriptájába temettethesse.

A CT-vizsgálatokat a Semmelweis Egyetem Radiológiai Klinikáján végeztük 2019ben (2. ábra). Lábtól felfelé haladtunk, kezdetben csontablakolást használva, majd a medence aljától átablakoltunk a lágyrészekre. Felfelé haladva jól láthatók a nagyajkak, a hüvelybemenet, majd az anus is.

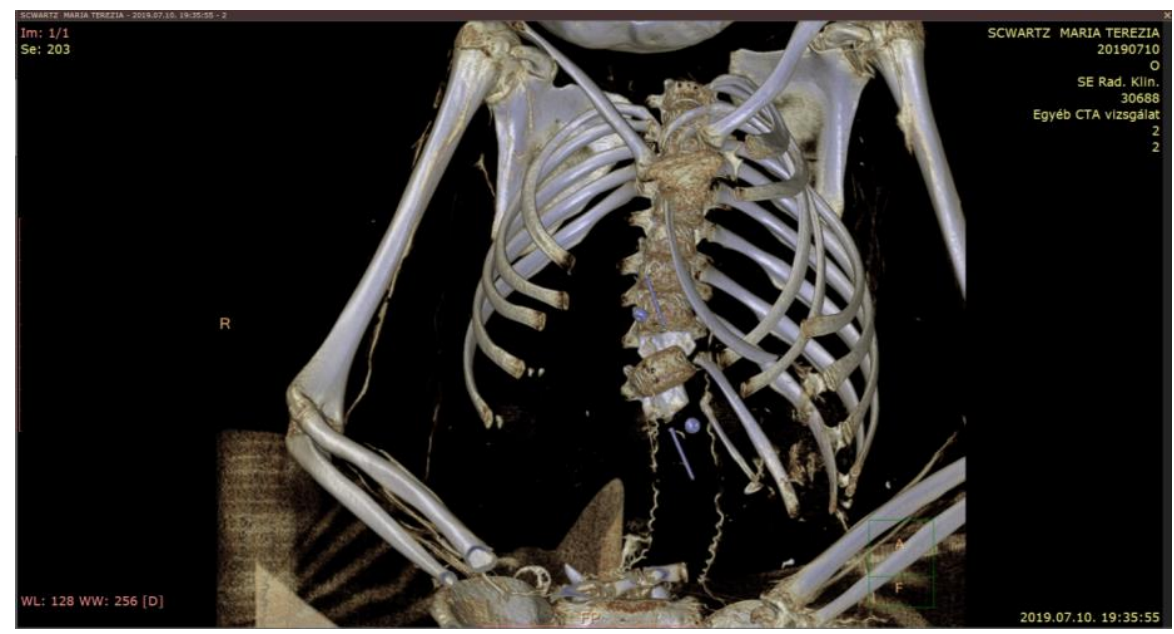

2. ábra: A mellkas 3D rekonstrukciója (felvétel: Radiológia Klinika, Semmelweis Egyetem) Fig. 2: 3D reconstruction of the chest (image: Department of Radiology, Semmelweis University)

A boncolás nyoma a symphysysnél válik elöször láthatóvá. A hosszanti metszést egészen a symphysis aljáig levitték. Felfelé haladva felismerhetővé válik a hólyag a kismedencében. Jól ábrázolódnak a belek. A bélrendszer levegösen összetömörült széklettel van teli. A medencében végig bélsárral telve ábrázolódik a rectum (3. ábra).

A combfej magasságában a peritoneum mellső lemezét is megnyitották, hogy belássanak a testbe. A bőrmetszés szélén itt-ott csomókként ábrázolódó képletek a korabeli varrat nyomai.

A comboknál jól látszódik az izomzat valamint a zsírszövet szárazanyag tartalma. A bőr nincs a csontra rátapadva, a bör-csont közötti távolság nagy, amit -1000 HU, azaz levegőnek megfelelő denzitású anyag tölt ki. Ez alapján feltételezhetjük, hogy a kislány kövérkés lehetett, a levegővel teli rész a korabeli zsírszövet helye.

$\mathrm{Az}$ acetabulum hátsó columnájában intraossealis hypodensytások figyelhető meg. Az os iliumban szimmetrikus, de nem egyforma nagyságú felritkulások láthatók. A csontok trabecularis szerkezete erősen látszódik. A csípőlapátokban molyrágásszerü hypointensiv foltok vannak, a cortex megkímélésével. A jobb iliumban scleroticus szélü, 3,3 mm átmérőjü gyürüszerü képlet látható. 


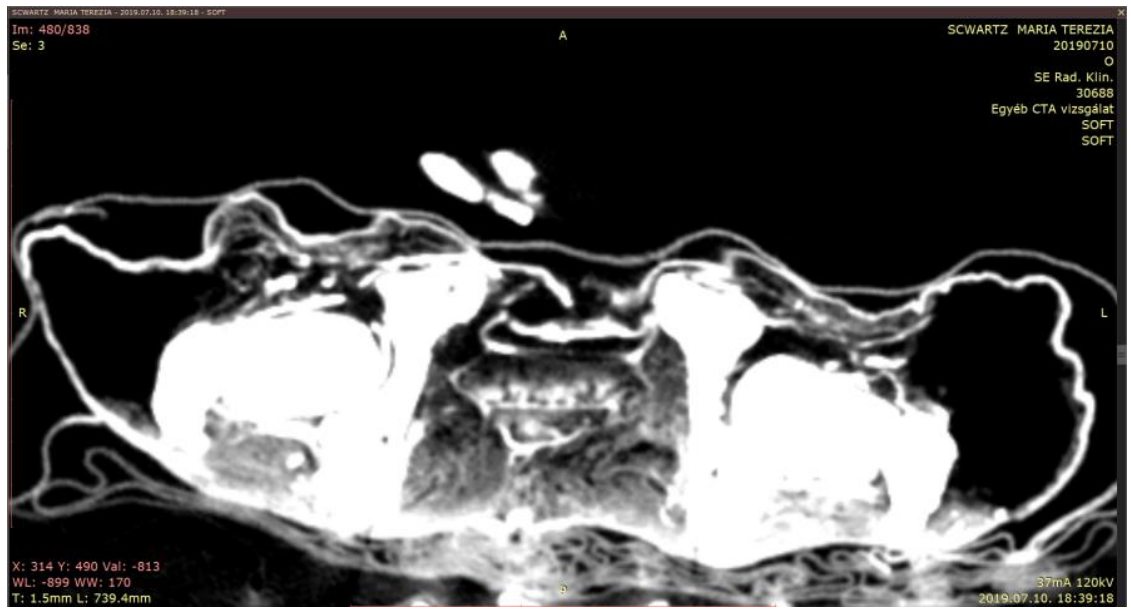

3. ábra: A kismedencei régió lágyrészeket (légtartalmú szöveteket) jól ábrázoló ablakbeállítással

(WL: -899, WW: 170). Jól látszódnak a faeces-sel teli belek. Megfigyelhető a hólyag és a börmetszés nyoma is (felvétel: Radiológia Klinika, Semmelweis Egyetem).

Fig. 3: The pelvic region with a window setting that well depicts soft parts (WL: -899, WW: 170).

The intestines full of faeces are clearly visible. Traces of bladder and skin incision can also be observed (image: Department of Radiology, Semmelweis University).

Felfelé haladva a sacrum középmagasságában, elöl a bőrön megjelenik a bal oldali haránt irányú börmetszés nyoma, hullámos vonalként ábrázolódva. Kicsivel feljebb láthatóvá válik a jobb oldali haránt bőrvarrás nyoma is. A test mindkét oldalán haránt irányban egészen a csípőlapáton túlra kivitték a metszést, annak érdekében, hogy minél jobban feltárhassák a hasi régiót.

A sacrum fölött post mortem hiányoznak a csigolyák és a belső szervek. A háton jól kivehető a post mortem börhiány; a halál után lesüllyedt testnedvek következtében vélhetően a bőr és a belső szervek is elenyésztek. Van, ahol a teljes háti bör hiányzik, így a csigolyák ezen a börhiányos területen keresztül a kripta feltárása során akadály nélkül kieshettek a testböl.

A mellkasüregben megjelennek az első háti csigolyák. A csigolyákon extrém hypervascularitás nyomai figyelhetők meg (4. ábra).

A zárólemez teljesen ép, de felfelé haladva a szeleteken, elérve a csigolyatest közepét, a csigolyát tápláló, Y alakban lefutó basivertebrális véna körül nagyobb méretü hypodens területek ábrázolódnak. Köztük több olyan is, amelyik a csigolyatest corticalis régióját átszakítja. Ezekbe a hypodens részekbe belemérve a levegő denzitásértékének megfelelő -1000 HU értéket kaptunk. Ez jelentheti azt, hogy ezek valaha levegővel telt üregek voltak, de valószínúbb, hogy a teret kitöltő anyag post mortem megsemmisült.

A mellkast ábrázoló CT-szeleteket magas ablakközép és tág ablakszélesség mellett is átnéztük. Megállapítható, hogy kevés lágyrész őrződött meg. A jobb oldalon kifejezettebb volt a börhiány, ott nem maradtak meg a szervek. A bal oldalon azonban izom- és egybefüggő tüdőmaradvány ábrázolódik. Visszaváltva a csontablakra, a mellürben dorsalisan megmaradt szövetben apró, hyperdens, kölesként szétszórt, gyöngyszerü képletecskék láthatók. Annak érdekében, hogy elkerüljük a volumenátlagolást, ránagyítottunk a gócokra, és azok denzitását megmérve kiderült, hogy ezek a gócok 
egyértelmüen meszes tartalmúak. Ezek a mészgyöngyök több szeleten át is megfigyelhetők.

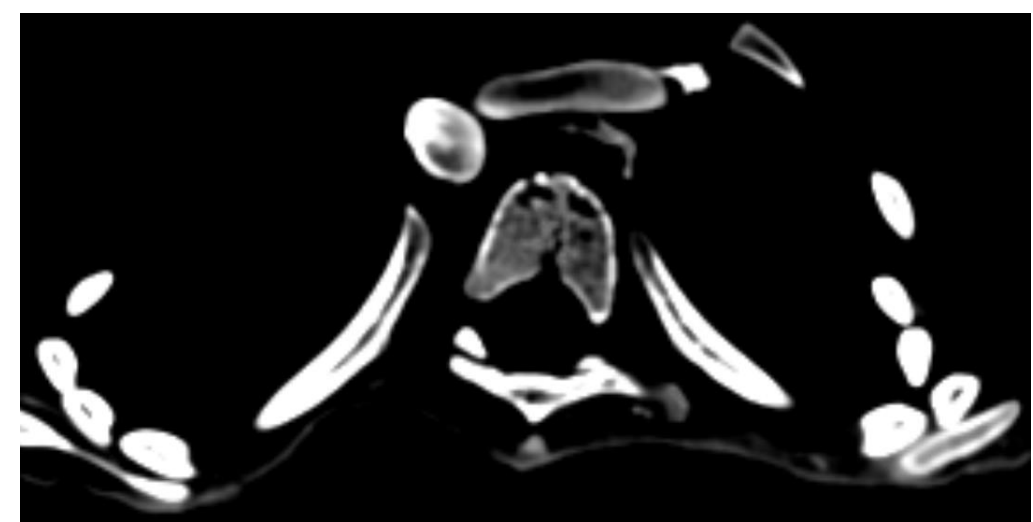

4. ábra: A basivertebrális véna körüli nagyobb kiterjedésủ hypodens területek (felvétel: Radiológia Klinika, Semmelweis Egyetem).

Fig. 4: Extensive hypodense areas are visible around the basivertebral vein (image: Department of Radiology, Semmelweis University).

\section{Paleomikrobiológiai vizsgálatok}

Swartz Mária Terézia több szövetmintájából is kimutatható volt a Mycobacterium tuberculosis (Donoghue és mtsai 2020). A test radiológiai vizsgálata súlyos tuberkulózisra utaló elváltozásokat mutatott. Nagyon valószínű, hogy a gyermek halálában közrejátszhatott ez a betegség. A XVIII. századi Vácott magas volt a tbc-fertőzöttség (Fletcher és mtsai 2003, Donoghue és mtsai 2011, Pap és mtsai 2017, Donoghue és mtsai 2020).

\section{A mikrotörténeti kutatás eredményei}

A Swartz-családban 1773 és 1792 között 13 gyermek született. Az anyakönyvi bejegyzések szerint 7 gyermek kora-kisgyermekkorban meghalt.

Mária Terézia második gyerekként született 1774 szeptemberében. A halotti anyakönyvi bejegyzés megnehezítette a beazonosítást, mert halálát Anna Mária néven, 5 évesként jegyezték be. Az elvégzett antropológiai életkorbecslés (9-10 év) a koporsón szereplő adatokat erősítette meg, amely szerint: Schwartzel Mária Terézia, (meghalt) 1784-ben, 10 éves korában.

\section{Megbeszélés}

A Semmelweis Egyetem Radiológiai Klinikáján elvégzett CT-vizsgálat során azt vártuk, hogy sikerül kideríteni, mi okozta a gyermek halálát, amely miatt boncolták. A XVIII. század második felében ugyanis hatósági boncolást csak kivételes esetben rendeltek el, például gyilkosság, gyanús halálesetek, talált holttestek, hirtelen halál, öngyilkosság esetén.

A mellkasban lévő sok apró elmeszesedett képlet felveti a rapid miliaris tbc gyanúját. Ha a Mycobacteriumok a vérárammal szóródnak, és más szervekben is megtelepednek, tüdőn kívüli szervi, extrapulmonalis tuberkulózis alakulhat ki. A csigolyák állapota és a 
két ilium lyticus területei felvetik a csont-tbc valószínüségét. A csont-tbc főként a hát- és az ágyéki csigolyákat érinti, de előfordulhat a csípőcsontban is.

A csigolyákon a basivertebrális véna területén, annak Y alakú lefutása mentén hypodens mészhiányos területek figyelhetők meg. Elképzelhető, hogy magát a drenáló ereket látjuk. Tíz éves korában még az intenzív fejlődés időszakában van egy gyermek, ami megmagyarázná, hogy a basivertebralis erek miért ennyire kifejezettek. Jelen esetben azonban nem zárható ki, hogy itt a csigolyatestekben a tbc baktérium csontpusztító munkáját látjuk. A kiöblösödött üregek több helyen a cortexet is átszakítják. A cortexen erősödés, ún. mészgyöngyök figyelhetők meg, amelyek már a gyógyulási folyamat megindulására utalnak.

Úgy véljük, Swartz Mária Terézia esetében a csigolyagyulladás bakteriális eredetü, valószínüsíthetően tbc-fertőzés okozta.

A gyermek halálában biztosan közrejátszott a tbc fertőzés. A jelek szerint rapid miliaris tbc-je és extrapulmonalis csont-tbc-je lehetett. Ezt a radiológiai vizsgálatok során felállított diagnózist erősíti meg a korábban elvégzett paleomikrobiológiai vizsgálat is, amely szerint szervezete tartalmazta a Mycobacterium tuberculosis maradványát, a pulmonalis és az extrapulmonalis mintákban egyaránt (Donoghue és mtsai 2020).

A tbc-s fertőzés mellett nem zárható ki az sem, hogy a gyermek halálát appendicitis okozhatta. Vakbélgyulladás esetén előfordul, hogy a bélmüködés leáll, és a beteg nem tud székelni. Mária Terézia felfújódott beleiben nagymennyiségü szárazanyag, a leülepedett korabeli bélsár maradványa látható. Ez arra utal, hogy minden bizonnyal nem tudott székletet üríteni. Tehát mivel a belek feltünően tele vannak, nem kizárt, hogy appendicitis-be halt bele.

A vizsgálatok során kiderült, hogy a testet a gyakoribb Y metszés helyett fordított kereszt alakú metszéssel vágták fel. A hason hatalmas vágás látható, a metszést mindkét oldalon egészen a csípőlapáton túlra kivitték haránt irányban, hogy minél jobban feltárhassák a hasi régiót. Feltételezhetjük, hogy halála előtt hasi panasza lehetett, ezért a boncolás során arra a területre koncentrálhattak, hogy megtalálják a halált okozó elváltozás nyomát.

A feltételezett hasi panaszokat a tbc is okozhatta. A gyomor-bél tbc a XVIII. században gyakori lehetett, mert a nyers, pasztörizálatlan tej volt a Mycobacterium bovis baktériumok fö terjesztője. A betegség másik kialakulási módja a tüdőből felköhögött fertőző köpet lenyelése. A bélcsatornában az elváltozások körkörösen elhelyezkedő fekélyek formájában jelennek meg, elsősorban a coecumban, amelyek hegesedése bélelzáródáshoz vezet.

A bélsárral teli belek tehát egyaránt utalhatnak appendicitis-re és extarpulmonaris szervi bél tbc-re is.

A vizsgálatok során egy harmadik lehetséges halálok is felmerült. Voltak olyan erek, ahol elmeszesedett arteriosclerosisra utaló nyomokat találtunk. Az artériák fala egy-egy helyen meszesedett, ami nem jellemző egy 10 éves gyermekre. Vannak olyan fertőző gyermekbetegségek, mint pl. a diphteria és a varicella, amelyek melléktünetként arteriosclerosist okoznak, de ez idővel megszünik. Azaz átmenetileg gyermekkorban is kialakulhatnak szklerotikus részek az erekben, de hogy ezek láthatóvá is váljanak, a betegnek túl kellett élnie a fertőzést. Mária Terézia esetében bár találtunk az erekben meszesedést, mégsem feltételezzük az elöbbiekben említett fertőzö betegségeket, mert nincs a bőrön kiütés vagy hólyagnyom, ráadásul mindenképpen életben kellett volna maradnia ahhoz, hogy az arteriosclerosis manifesztálódhasson. 
A radiológiai vizsgálatok során arra is kerestük a választ, hogy mi történt a boncolás során kivett belső szervekkel. Vajon visszahelyezték-e ezeket a testbe, és ha igen, akkor ezt anatómiai rendben tették-e meg. Erre a kérdésre Swartz Mária Terézia vizsgálata során nem kaptunk választ, mivel a radiológiai felvételeken nagyon kevés belső szerv látható. Ezek valószínűleg a hát post mortem elenyészése miatt hiányoznak, vélhetően lebomlottak.

\section{Következtetések}

A tanulmány a Magyar Természettudományi Múzeum Embertani tára Múmia Gyüjteményében örzött gyermek, Swartz Mária Terézia mumifikálódott maradványain végzett multidiszciplináris, antropológiai, paleopatológiai, radiológiai és paleomikrobiológiai vizsgálatok eredményeit mutatja be.

A Vácott élt Swartz Mária Terézia (No.76., leltári szám: 2009.19.76.) 10 éves korában, 1784. január 26-án hunyt el.

A makroszkópos vizsgálatok során a testen két vágás volt észlelhető: a hosszanti vágás a manubrium sternitől a symphysisig tart, az erre merőleges, haránt irányú a két csípőlapátot köti össze. A sebszéleket később bevarrták, a varrófonal is részben megmaradt. A boncolás egyértelmüen a halál okának kiderítésére irányult. Feltételezhetjük, hogy a gyermeknek hasi panasza lehetett, ezért a boncolás során arra a területre koncentrálhattak, szélesen feltárva a hasi régiót, hogy megtalálják a halált okozó elváltozás nyomát. A gyermek halálában biztosan közrejátszott a rapid miliaris tbc és extrapulmonalis csont-tbc; amit a radiológiái vizsgálatok kimutattak, és a paleomikrobiológiai vizsgálat is megerősített (a Mycobacterium tuberculosis maradványát pulmonalis és extrapulmonalis mintákban is detektálták).

Egy másik lehetséges halálok az appendicitis. Vakbélgyulladás esetén előfordul, hogy a bélmüködés leáll. Erre utalnak a szárazanyaggal teli, felfúvódott belek, és az a tény, hogy a gyakoribb Y metszés helyett a testet fordított kereszt alakú metszéssel vágták fel, egészen a csípőlapáton túl, hogy minél jobban feltárhassák a hasi régiót. A gyermeknek halála előtt hasi panasza lehetett, valószínüleg ezért koncentráltak erre a területre a boncoláskor. A feltételezett hasi panaszokat esetleg extrapulmonalis gyomor-bél tbc is okozhatta.

Tanulmányunkat tisztelettel és szeretettel ajánljuk Dr. Marcsik Antóniának és Dr. Gyenis Gyulának születésnapjuk alkalmából!

Köszönetnyilvánítás: A kutatás az OTKA 61155, K73441, K78555 és az NKFIH K 125561 számú projektek támogatásával valósult meg.

\section{Irodalom}

Cseplák, Gy., Szikossy, I., Pap, I. (2016): A váci múmiákról. Antropo-medicinális tanulmányok 52 váci múmia vizsgálatáról egy börgyógyász fényképes jegyzeteivel. Semmelweis Kiadó és Multimédia Stúdió Kft., Budapest.

Donoghue, H.D., Pap, I., Szikossy, I., Spigelman, M. (2011): Detection and characterization of Mycobacterium tuberculosis DNA in 18th century Hungarians with pulmonary and extrapulmonary tuberculosis. Yearbook of Mummy Studies, 1: 51-56. 
Donoghue, H.D., Spigelman, M., Szikossy, I., Pap, I. (2020): Publikálatlan egyéni adatok. Kézirat. Fletcher, H.A., Donoghue, H.D., Holton, J., Pap, I., Spigelman, M. (2003): Widespread occurrence of Mycobacterium tuberculosis DNA from 18th-19th century Hungarians. American Journal of Physical Anthropology, 120: 144-152. DOI: 10.1002/ajpa.10114

Pap, I., Susa, É., Józsa, L. (1997): Mummies from the 18th-19th century Dominican Church of Vác, Hungary. Acta Biologica Szegediensis, 42: 107-112.

Pap, I., Józsa, L., Repa, I., Bajzik, G., Lakhani, S.R., Donoghue, H.D., Spigelman, M. (1999): 1819th century tuberculosis in naturally mummified individuals (Vác, Hungary). In: Pálfi, Gy., Dutour, O., Deák, J., Hutás, I. (Eds) Tuberculosis: Past and Present. Budapest - Szeged. pp. 419-428.

Pap, I., Pálfi, Gy., Molnár, E., Karlinger, K., K. Kovács, B., Korom, Cs., Schultz, M., SchmidtSchultz, T.H., Spigelman, M., Donoghue, H.D., Kustár, Á., Szikossy, I. (2017): A tuberkulózis előfordulása egy XVIII. századi váci családban. Anthropologiai Közlemények, 58: 37-47. DOI: $\underline{10.20330 / \text { AnthropKozl.2017.58.37 }}$

Susa, É. (1995): Előzetes jelentés a váci Fehérek temploma kriptafeltárásáról. Anthropologiai Közlemények, 37: 192-193.

Susa, É., Józsa, L. (1995): A múmiakészítés technikája és eredményei az ókortól napjainkig. Anthropologiai Közlemények, 37: 100-118.

Szikossy, I., Bernert, Zs., Pap, I. (1997): Anthropological investigation of the 18th-19th century ossuary of the Dominican Church,Vác, Hungary. Acta Biologica Szegediensis, 42: 145-150.

Tragor Ignác Múzeum (1995): A váci Fehérek temploma feltárási dokumentációja. ND 95.3.2.1262.

Zomborka, M. (1996): Vác „Fehérek temploma” kriptafeltárás. 1994-95. Magyar Múzeumok, 2(1): 3-7.

Levelezési cím:

Szikossy Ildikó

Mailing address:

Embertani tár

Magyar Természettudományi Múzeum

Ludovika tér 2-6.

H-1082 Budapest

Hungary

szikossy.ildiko@nhmus.hu 